\title{
音声・ビデオ通信における端末間同期制御の効果
}

\section{Effects of Group Synchronization Control in Voice and Video Communica- tions}

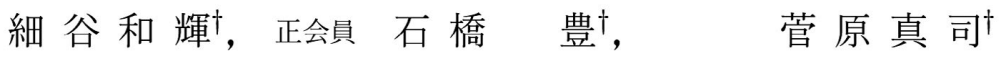 \\ Kazuki Hosoya $^{\dagger}$, Yutaka Ishibashi $^{\dagger}$ and Shinji Sugawara ${ }^{\dagger}$
}

\begin{abstract}
By subjective assessment, this paper investigates the effects of group (or inter-destination) synchronization control in multipoint communications where users have a conversation with each other by using voice and video. The results of our assessment show that the fairness among the users can be kept high by using the group synchronization control in networked competitive work. We also demonstrate that the synchronization quality of networked collaborative work in which the interactivity is not so important can be improved by using the group synchronization control. However, the group synchronization control deteriorates the easiness of networked collaborative work in which the interactivity is important.
\end{abstract}

キーワード : 多地点間通信, 音声, ビデオ, 端末間同期制御, 主観評価

\section{1. まえ がき}

利用者が音声やビデオ等を用いて, 会話, 競合作業, およ び協調作業を行う多地点間通信が注目されている ${ }^{1) 2)}$. し かし，サービス品質 (QoS: Quality of Service) 保証のな いネットワークを介して，これらのメディアを転送すると， ネットワーク遅延やその摇らぎ等により, 端末間でメディ アの時閒関係が乱される恐れがある。これはメディアの出 力品質を大きく劣化させる要因となる. また, 利用者間でメ ディアの出力タイミングが異なると, 会話, 競合作業, およ び協調作業において, 発言の機会の公平性が損なわれたり, 作業が成立しなくなる可能性が生じる ${ }^{3) 4) . ~}$

文献 3) では, 分散仮想環境における競合作業として,ア バタと音声を用いた早押しクイズ形式の名前当てゲームを 対象とし，ネットワーク遅延が公平性に及ぼす影響を明ら かにしている. その結果, 利用者間でネットワーク遅延に差 が生じ, 端末間で出力タイミングが異なることにより, 公平 性が劣化することを示している.

このような問題を解決するために, 複数端末間でメディア の出力タイミングをそろえる端末間同期制御 ${ }^{5)}$ が必要とな る. 文献 5) では, 一つのメディア発生源から二つのメディア 出力先にビデオと音声を送信し, 客観評価により, メディア

2008 年 8 月 21 日受付, 2008 年 9 月 25 日採録

†名古屋工業大学 大学院 工学研究科 創成シミュレーション工学専攻

(⿳亠丷厂 466-8555 名古屋市昭和区御器所町, TEL 052-732-2111)

$\dagger$ Department of Scientific and Engineering Simulation, Graduate

School of Engineering, Nagoya Institute of Technology

(Gokiso-cho, Showa-ku, Nagoya 466-8555, Japan)
出力先における端末間同期制御の有効性を示している.し かし,この文献では, メディア発生源からメディア出力先へ の単方向の通信しか扱わ机ていない. 双方向通信に対する 端末間同期制御の効果を調查した研究として, 文献 6) があ る. 文献 6)では, 対戦形式のネットワーク型シューティン グゲームを扱い, サーバを介して,プレイヤは互いにファイ タの位置や発射した弾のコンピュータデータを送受信して いる，そして，客観評価により，端末間同期制御の有効性を 明らかにしている.しかし，この文献では，主観評価試験は 行われておらず, 端末間同期制御が主観的にどの程度有効 であるかは明らかにされていない．

そこで本論文では, 文献 3) で扱わ机た競合作業である早 押しクイズ形式の名前当てグームに加えて, 協調作業として ネットワーク上で行うじゃんけん（以下, オンラインじゃん けんと呼ぶ出 および数字を読み上げる作業を対象とする. そして, 主観評価試験により, 多地点間通信に対する端末間 同期制御の有効性を明らかにする.

以下では, まず, 2 章で端末間同期制御について説明し, 3 章で作業内容を述べる. 次に, 4 章で実験システムと主観評 価方法を述べ, 5 章で実験結果について考察する.

\section{2. 端末間同期制御}

端末間同期制御とは, メディア発生源から複数のメディア 出力先に送信されたメディアユニット (メディア同期制御 のための処理単位. 以下, MU と略す. 例えば, ビデオピク チャ) の出力タイミングをメディア出力先の間でそろえる 制御である，出力タイミングに関する情報を制御情報とし 
て端末間で送受信することにより, 基準とすべき出力タイ ミングを決定する.ただし，この出力タイミングは MU の 発生時刻にバッファリング時間 $\Delta$ を加えたものである. ま た, $\Delta$ の值は, $\Delta_{\mathrm{L}}$ から $\left.\Delta_{\mathrm{H}}{ }^{7}\right)$ の範囲内でネットワーク遅延 の大きさに応じて動的に変化する. 端末間で同じ $\Delta$ の值を 用いることによって端末間の同期をとる.

端末間同期制御方式として，マスタ・スレーブ端末方式， 同期マエストロ方式, 分散制御方式 5) が提案されている. 本 論文では, 分散制御方式を用い, 端末間同期を実現する。こ れは, 本論文で扱う実験システムが Peer to Peer(P2P) モ デルに基づくため, 分散制御方式の方が他の方式に比・゙親 和性が高いからである.

分散制御方式では, すべての端末が自端末の MU の出力 タイミングに関する情報を他端末に送信する. 各端末は全 端末の情報を持つことになり，この情報から基準とすべき 出力タイミングを決定する. 本論文では, 基準とすべき出 カタイミングとして, 全端末の中で最も遅い出力タイミン グを選択する ${ }^{5)}$.このタイミングに各端末の出力タイミン グを近づけることで端末間同期を実現する.

\section{3. 作業 内 容}

本論文では，三人の利用者が音声・ビデオ通信を用いて， 作業を行う場合を対象とする*. 競合作業として, ITU-T P.920 の Name-guessing task ${ }^{9)}$ を拡張した早押しクイズ形 式の名前当てゲームを扱い, 協調作業には, オンラインじゃ んけんおよび数字を読み上げる作業を採用する.協調作業 にこれら 2 種類の作業を用いるのは, 二つの作業でインタラ クティブ性の重要度が異なるためである. 数字を読み上げ る作業の方がオンラインじゃんけんよりもインタラクティ ブ性の重要度が高い. 以下では, これら三つの作業内容に ついて説明寸る。

\section{1 早押しクイズ形式の名前当てゲーム}

この作業では, 三人の利用者のうち一人が問題の出題者 となり, 残りの二人が質問者となる. 出題者は, リストの中 からジャンル (例: 果物) を一つ選び, キーワード (例: リ ンゴ)を決めて, 口頭で質問者二人にジャンルを伝える (例: 「ジャンルは果物です」. 図 1(a) 参照). そして, 質問者は, 出題者が決めたキーワードを当てる，質問者は，「はい」と 返事をすると同時に, 片手を挙げる (出題の語尾を聞いた後 に返事をするように指示. 図1(b)). 出題者は, 挙手の古かっ た方を片手で指しながら，口頭で発言権を与える(図1(c)). 質問者の回答が正解の場合, 出題者は「正解です」と言い, 新たにジャンルを選ぶ. 一方, 回答が不正解の場合, 出題者 は「違います」と言い, 質問者は, 再度挙手をし, キーワー ドを当てようとする.

\section{2 オンラインじゃんけん}

この作業では, 掛け声をかける利用者 (以下, 掛け手と呼

*筆者らは, ビデオの代わりにアバ夕 (仮身) を用いる実験も行っている. そして, 本論文の結果とほとんど同じ結果を得ている8).
質問者 出題者 質問者

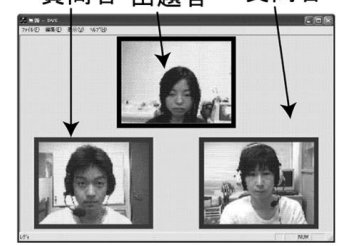

(a) 出題者がジャンルを言う 挙手の早いほうに発言権が 与えられる

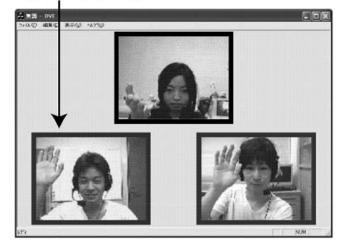

(c) 出題者が発言権を与える

図 1 早押しクイズ形式の名前当てゲームの表示例 Displayed images in name-guessing task like fastest fingers first.

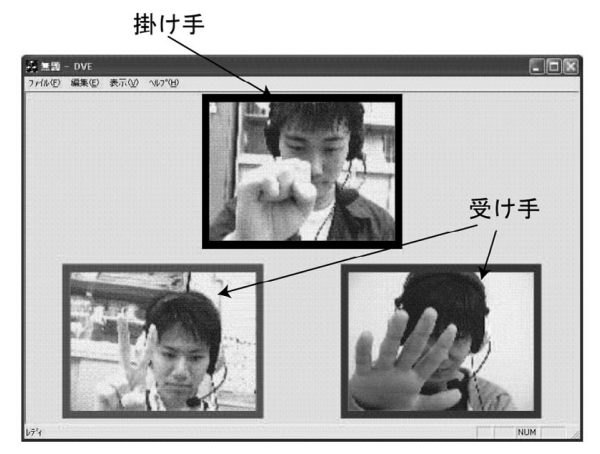

図 2 オンラインじゃんけんの表示例

Displayed images in networked rock-paper-scissors.

ぶ)一人と掛け手の声に合わせる利用者 (以下, 受け手)二人 に分かれる. 三人の利用者のうち一人の掛け手が「じゃん けんぼん」と掛け声をかけ, 利用者は, グー, チョキ,パーの いずれかを出す (図 2 参照). そして, これを繰り返し行う.

\section{3 数字を読み上げる作業}

この作業では, 利用者が順番に 1 から 10 までの数字を繰 り返し読み上げる. 数字を読み上げる利用者の順番は予め 決められており, 利用者は, 自分の一つ前の順番の利用者が 数字を読み上げた声が聞こえると直ちに，その次の数字を 読み上げる.また, 利用者は, 数字を読み上げる際, 同洔に その数字を指で表す動作も一緒に行う (図 3 参照).

\section{4. 実験システムと主観評価方法}

\section{1 実験システム}

実験システムは, 図 4 に示すように, 3 台の端末とネット ワークエミュレータ $\left(\mathrm{NIST} \mathrm{Net}{ }^{10)}\right)$ から構成される. NIST Net は, 端末間で送受信されるパケットに対して, パレート 正規分布 ${ }^{10)}$ に従う付加遅延を発生させるために用いられ る.また, 各 MUはUDPにより転送される. 早押しクイ ズ形式の名前当てゲーム, およびオンラインじゃんけんを 作業として扱う場合, 付加遅延 3 の值を $0 \mathrm{~ms}$ とし, 付加遅 


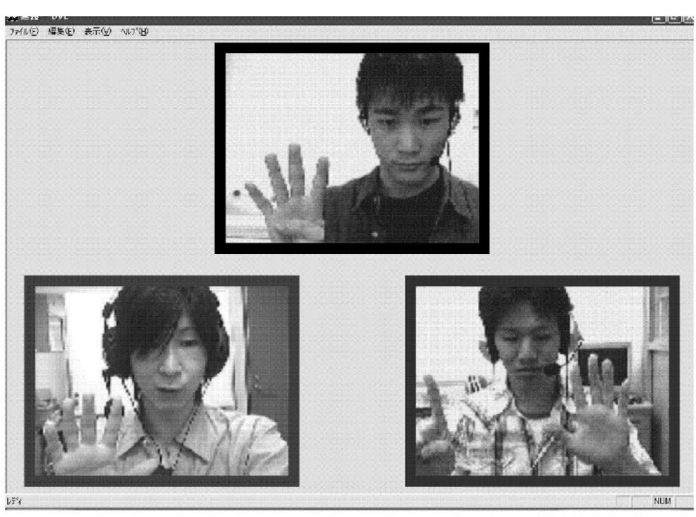

図 3 数字を読み上げる作業の表示例 Displayed images in number-counting task.

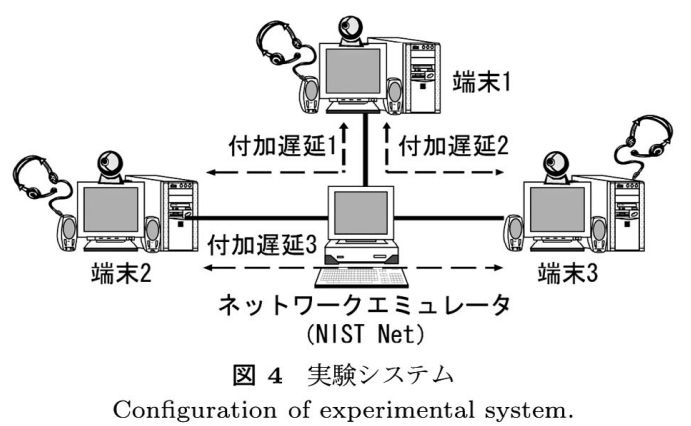

延 1,2 の平均を $50 \mathrm{~ms}$ から $250 \mathrm{~ms}$ まで $50 \mathrm{~ms}$ 間隔で変化さ せる.また, 数字を読み上げる作業を扱う場合, 付加遅延 1 , 2 の平均を $50 \mathrm{~ms}$ に固定し, 付加遅延 3 の平均のみを $50 \mathrm{~ms}$ から $650 \mathrm{~ms}$ まで $100 \mathrm{~ms}$ 刻みで変化させる場合 (方法 1 ), 付 加遅延 1 の平均を $50 \mathrm{~ms}$ に設定し, 付加遅延 2,3 の平均を 同一にして方法 1 と同様に変化させる場合 (方法 2), 付加 遅延 $1,2,3$ 0)平均を等しくし, 方法 1 と同様に変化させる 場合 (方法 3) の 3 通りの方法を用いる. なお, 付加遅延の 標準偏差を $10 \mathrm{~ms}$ とする。

主観評価試験では, 端末間同期制御を行う場合と行わない 場合を扱う。端末閒同期制御を行う場合には，メディア内同期 制御とメディア間同期制御 ${ }^{11)}$ も行うものとする. また, 端末 間同期制御を行わない場合にも，これらの制御を行う。なお， メディア内およびメディア間同期制御にはVTR(VirtualTime Rendering) アルゴリズム ${ }^{12)}$ を用いる.このアルゴ リズムは, ネットワーク遅延の摇らぎに応じて伸縮可能な 仮想時間軸を持ち, その仮想時間軸に沿って, MU を出力す ることにより，メディア同期を達成しようとする.

\section{2 主観評価方法}

主観評価には ITU-R BT.500-11 ${ }^{13)}$ の単一刺激法を拡張 して用いる. 被験者は 21 歳から 24 歳までの男女 20 名で ある。

早押しクイズ形式の名前当てゲームでは, まず, 被験者は 評価の前に, 評価の基準となるネットワーク遅延を付加し ない状態で 40 秒問会話を行う.その後, 遅延を付加した状 態で同じ時間にわたり会話を行い, 表 1 に基づき発言の機 会の公平性を, 表 2 に基づきインタラクティブ性および総
表 15 段階品質尺度

Five-grade scale of fairness.

\begin{tabular}{c|c}
\hline \hline 評点 & 評洒基準 \\
\hline \hline 5 & 公平である \\
\hline 4 & どちらかと言えば公平である \\
\hline 3 & どちらとも言えない \\
\hline 2 & どちらかと言えば不公平である \\
\hline 1 & 不公平である \\
\hline
\end{tabular}

合品質の評価を行う。ここで, 付加遅延の呈示はランダム に行うものとする. インタラクティブ性として, 出題者は, 質問者を指名してから返答までの時間, 質問者は返事をし てから指名されるまでの時間に着目する。また, 総合品質 の評価は, 公平性とインタラクティブ性を合わせた評価で ある. 被験者は, 出題者 (端末 1) か質問者 (端末 2) のどち らかの立場になり，その立場での評価終了後, 立場を交替し て再度評価を行う。なお，もう一人の質問者 (端末 3 ) は著 者の一人が担当する.

オンラインじゃんけんにおいて, 被験者は評価の前に, 評 価の基準となるネットワーク遅延を付加しない状態で 10 秒 間じゃんけんを行う.その後, 遅延を付加した状態で同じ 時間にわたりじゃんけんを行い, 表 2 に基づき端末間同期 品質, インタラクティブ性, および総合品質の評価を行う. ここで, 付加遅延はランダムに呈示するものとする. 端末 間同期とは, 被験者の端末における各利用者が同期して動 作することである.この端末間同期が基準となる状態から， 遅れによりどの程度劣化したかを被験者は評価する.また， インタラクティブ性の尺度として, グー, チョキ,パーのい ずれかを出してから，最も遅い相手が動作するまでの時間 を用いる. 総合品質の評価は, 端末間同期品質とインタラ クティブ性を合わせた評価である. 被験者は, 掛け手 (端末 1) か受け手 (端末 2) 0いずれかの立場になり,その立場で の評価終了後, 立場を交替して再度評価を行う。なお，もう 一人の受け手 (端末 3 ) は著者の一人が担当する.

数字を読み上げる作業では, 評価を行う前に, 被験者は評 価の基準となるネットワーク遅延を付加しない状態で 20 秒 間作業を行う.その後, 遅延を付加した状態で同じ時間にわ たり作業を行い, 総合品質として作業のしやすさを表 2 に 基づき評価する. ここで, 付加遅延はランダムに呈示する ものとする.また, 簡単のため, 総合品質だけを評価項目と して採用している. 各被験者は, 端末 1,2 , および 3 のいず れかで評価を行い, その後, 順番に残りすべての端末で評価 を行う。

\section{5. 実験結果と考察}

\section{1 早押しクイズ形式の名前当てゲーム}

付加遅延 2 と付加遅延 1 の差 (以後, 遅延差と呼ぶ) に対 する出題者の公平性とインタラクティブ性の MOS 值をそ 
表 25 段階妨害尺度

Five-grade impairment scale for deterioration owing to network latency.

\begin{tabular}{c|c}
\hline \hline 評点 & 評価基準 \\
\hline \hline 5 & 遅れによる劣化がわからない \\
\hline 4 & 遅れによる劣化がわかるが気にならない \\
\hline 3 & 遅れによる劣化が気になるが邪魔にならない \\
\hline 2 & 遅れによる劣化が邪魔になる \\
\hline 1 & 遅れによる劣化が非常に邪魔になる \\
\hline
\end{tabular}

れぞれ図 5, 図6に示す. 図には, それぞれ $95 \%$ 信頼区間も 表記している (以下の図でも同様).

図 5 から, 端末間同期制御を行う場合, MOS 值は常に高 く維持されることがわかる。一方, 端末間同期制御を行わ ない場合の MOS 值は, 遅延差の絶対值が大きくなるにつ れて, 小さくなっていることが確認できる.また, 端末間同 期制御を行わない場合, 遅延差の絶対值が約 $100 \mathrm{~ms}$ を超え ると, MOS 值は 3 を下回ることがわかる.

図 6 より,端末間同期制御を行う場合, 行わない場合に 関らず, MOS 值に対する遅延差の影響は小さいことがわか る.また, 図 6 から, 早押しクイズ形式の名前当てゲームに おいて, 端末問同期制御がインタラクティブ性に及ぼす影 響はほとんどないことが確認できる。

また, 出題者の総合品質の MOS 値は図 5 の公平性の MOS 值の変化とよく似た傾向があることがわかった.これは, 端 末間同期制御がインタラクラィブ性に与える影響が小さい ことから, 公平性の MOS 值の変化が総合評価に及ぼす影 響が大きくなったためである。

さらに, 質問者の MOS 值は出題者のそれとほとんど同 じであった。

この他, 付加遅延 3 の平均を変化させる実験も行った結 果, 付加遅延 3 の平均が大きくなると, 端末間同期制御を行 わない場合, 質問者の公平性と総合品質の MOS 值が劣化 することがわかった。これは, 画面上では, 被験者から見て 他方の質問者が遅く挙手しているにも関らず，出題者にそ の質問者が指名される場合が生じるためである.

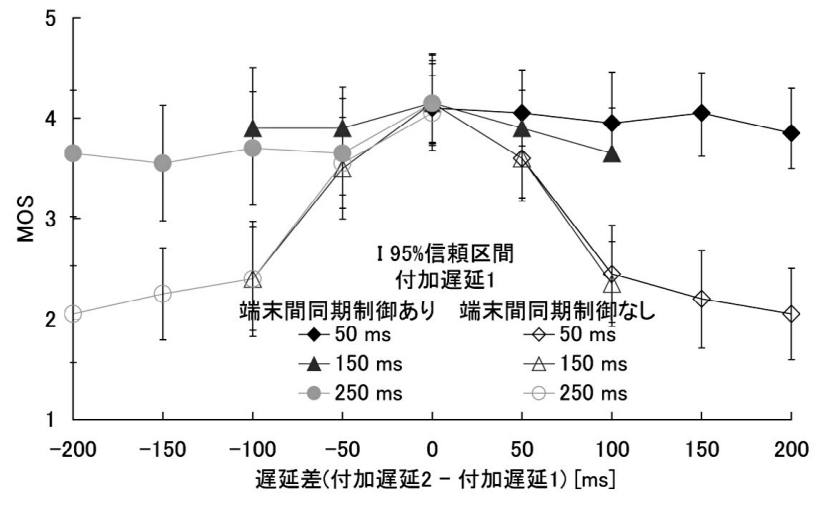

図 5 遅延差に対する出題者の公平性の MOS 値 MOS of fairness of examiner versus difference in network latency.

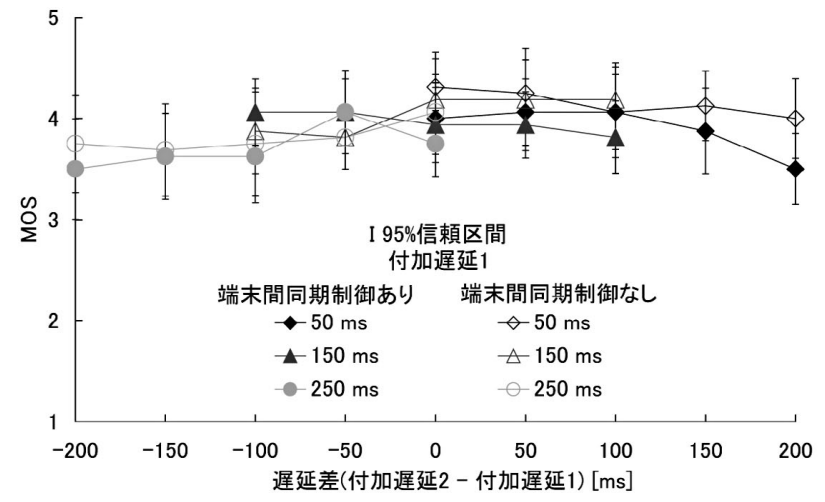

図 6 遅延差に対する出題者のインタラクティブ性の MOS 值 MOS of interactivity of examiner versus difference in network latency.

\section{2 オンラインじゃんけん}

\section{(1) 掛 け 手}

遅延差に対する掛け手の端末間同期品質の MOS 值を図 7 に示す.

図 7 では, 端末間同期制御を行う場合, 行わない場合とも に遅延差が正のとき，遅延差が大きくなるほど MOS 值は 小さくなっている．また, 遅延差が負のとき, MOS 值の変 化は遅延差に依存しない傾向にある。この理由として次の ことが挙げられる.被験者は, 端末間同期品質として, 最初 に動作した利用者と最後に動作した利用者の時間の差に着 目する. そのため, MOS 值は付加遅延 1,2の大きい方に依 存する. 遅延差が負のとき, 付加遅延 1 は付加遅延 2 より 常に大きい状態にある.このとき, MOS 值は付加遅延 1 に のみ依存し，ほぼ一定となる。

また, 図 7 から, 端末間同期制御を行うことで, 行わない 場合に比べ MOS 值が高く保たれていることがわかる。こ の理由は次の通りである. 端末間同期制御では, 自端末に おける MU の入力を付加遅延の大きさに応じて, 遅らせて 出力する.これにより, 利用者間の動作の時間的なずれが 小さくなったため, MOS 值は高くなっている.

さらに, 掛け手のインタラクティブ性および総合品質は, 掛け手の端末間同期品質と良く似た傾向にあることがわ かった.

この他, 付加遅延 3 の平均を変化させる実験も行った。 そ の結果, 端末間同期制御を行わない場合, 付加遅延 3 を変化 させても掛け手の MOS 值に変化はなかった．しかし,端末 間同期制御を行う場合, 付加遅延 3 の平均が大きくなると, $\Delta$ の值が付加遅延 1,2, および 3 の平均の中で最も大きい 值に依存し変化してしまうため, 端末間同期品質, インタラ クティブ性, および総合品質の MOS 值が劣化することが わかった。

\section{(2)受け手}

遅延差に対する受け手の端末間同期品質の MOS 值を図 8 に示す. 


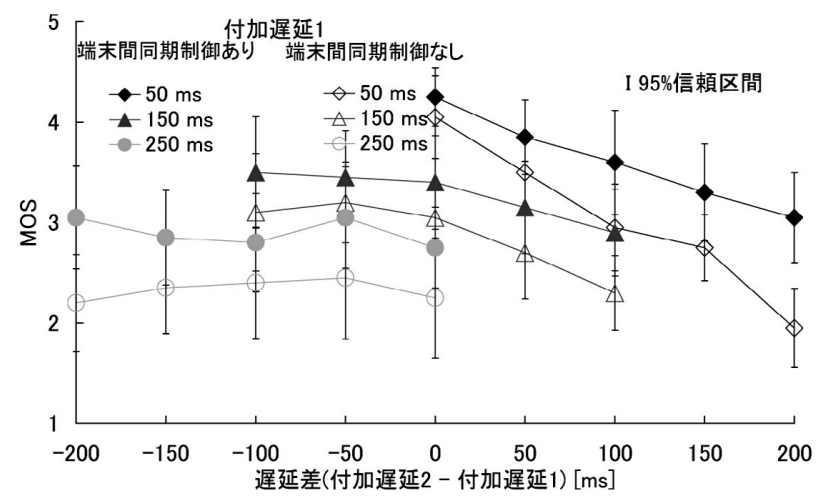

図 7 遅延差に対する掛け手の端末間同期品質の MOS 值 MOS of group synchronization quality of caller versus difference in network latency.

図 8 より, 付加遅延 1 の平均が $150 \mathrm{~ms}, 250 \mathrm{~ms}$ のときで は, 端末間同期制御を行う場合の MOS 值が行わない場合 の MOS 值に比べ, 小さいことがわかる.この理由として次 のことが挙げられる. 端末間同期制御を行わない場合, 遅 延差が負のときには, 他方の受け手 (端末 3 ) は端末 2 の被 験者よりも早く動作することになる。そして, 端末 2 の被 験者および掛け手の被験者は, 掛け声とほぼ同時に動作す る. 端末 3 の受け手の動作とこの動作の時間的な差は小さ いため, 被験者は大きな劣化を感じない.それに対し, 端末 間同期制御を行うと，掛け声とともに掛け手が最初に動作 し, その $\Delta$ 秒後に端末 2 の被験者と他方の受け手が動作す る.この $\Delta$ の值が付加遅延の大きさに応じて変化するため, 付加遅延が大きくなるほど MOS 值は下がっている.しか し, 図 8 において, 端末間同期制御を行いMOS 值が悪くな る場合でも, 最も小さい MOS 值は約 3 である.これは, 掛 け手における端末間同期制御を行わない場合の MOS 值の 劣化 (図 7 参照) に比べ大きな劣化ではないので, 端末間同 期制御を行う方が良いと言える。

また, 受け手のインタラクティブ性と総合品質は, 受け手 の端末間同期品質と良く似た傾向があることがわかった.

以上より，掛け手と受け手で同様に端末間同期制御を行 うと, 受け手では, 端末間同期制御を行わない場合よりも $\operatorname{MOS}$ 值が小さくなり得ることが確認できる. 今後の課題 として,この問題を解決するため, 会話の立場の違いを考虑 して端末間同期制御を拡張することが考えられる.

この他, 付加遅延 3 の平均を変化させる実験を行った結 果, 端末間同期制御を行う場合, 行わない場合に関らず, 付 加遅延 3 の平均が大きくなることで端末間同期品質, イン タラクティブ性, および総合品質の MOS 值が劣化するこ とがわかった.

\section{3 数字を読み上げる作業}

図 9 に付加遅延 3 に対寸る* 方法 1 における端末 1 の作 業のしやすさの MOS 值を示す. 図 9 より, 端末間同期制御 を行う場合の MOS 值が行わない場合の MOS 值に比べて

\footnotetext{
“5.1 と 5.2 では, 異なる立場間の遅延差の影響を調べているが, 数字を 読み上げる作業では, 利用者の立場に差がないため, 遅延差の影響は調 ベない.
}

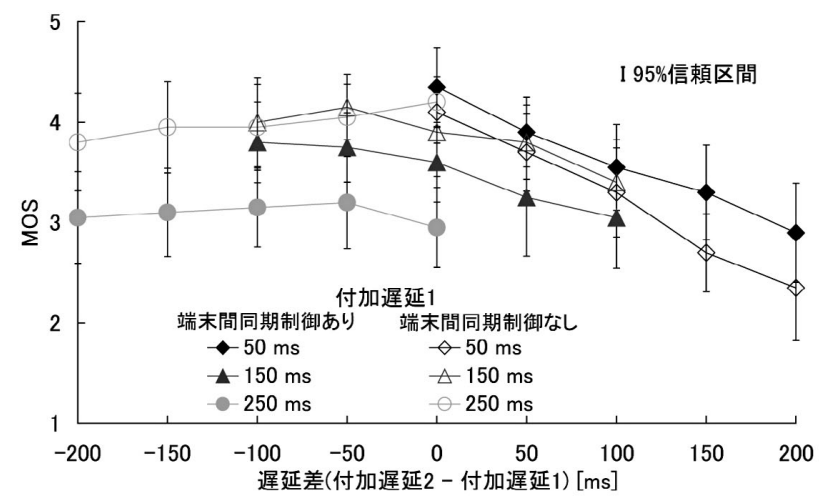

図 8 遅延差に対する受け手の端末間同期品質の MOS 值 MOS of group synchronization quality of receiver versus difference in network latency.

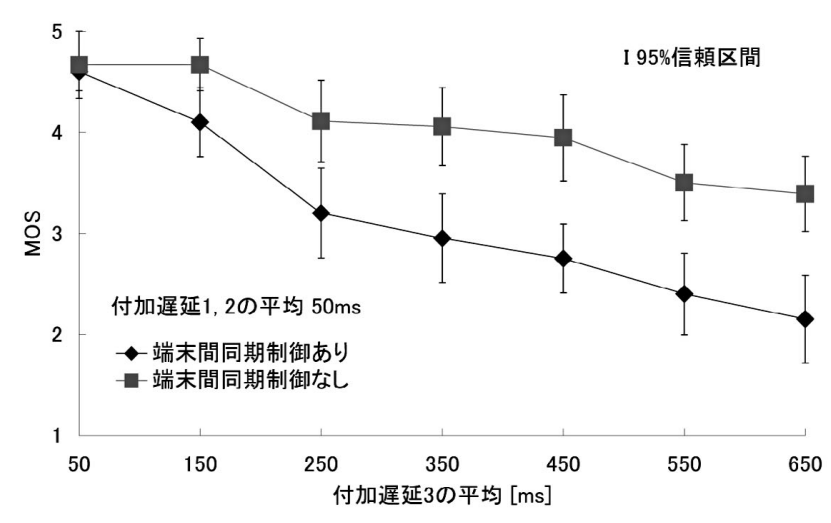

図 9 付加遅延 3 に対する方法 1 における作業のしやすさの $\operatorname{MOS}$ 值 (端末 1)

MOS of easiness of work in method 1 versus additional delay 3 (terminal 1).

小さいことが確認できる.この理由は次の通りである. 端 末間同期制御を行う場合では, 付加遅延 3 の平均が大きく なるとき，すべての端末においてバッファリング時間が増 加する. そのため, 読み上げられる数字の総数が端末間同 期制御を行わない場合に比べて減少する。この作業は, 制 限時間内により多くの数字を読み上げることが目的である ため, 読み上げた数字の総数が減少したことで, 被験者は大 きな劣化を感じる，そのため, 端末間同期制御を行う場合 の MOS 值の方が行わない場合のそ机に比べて劣化が大き くなる.

この他, 方法 1 における端末 2 では, 端末間同期制御を 行わない場合の MOS 值の劣化が他端末に比べて大きいこ とがわかった。これは, 端末 1 および 3 とは異なり,端末 2 では, 付加遅延 3 が大きくなると, 数字の順番が入れ替わっ て被験者に聞こえる現象が生じたためである。また，方法 2 では, 方法 1 に比べて, 端末間同期制御を行わない場合の MOS 值と端末間同期制御を行う場合の MOS 值の差が小 さくなった.これは, 方法 2 が三つの付加遅延のうち二つ が同じ平均を持ち変化するためである.さらに, 方法 3 に おいては, 三つの付加遅延の平均が同じであるため, 端末問 同期制御を行う場合と行わない場合の MOS 値の間にほと んど違いはないことがわかった. 


\section{6. むす び}

本論文では, 音声・ビデオ通信を用いて, 早押しクイズ形 式の名前当てゲーム, オンラインじゃんけん, 拉よび数字を 読み上げる作業を対象とし，主観評価試験により，端末間同 期制御が及ぼす影響を調査した。その結果, 作業の種類や 会話における立場の違いによって, 端末間同期制御が有効 な場合とそうでない場合があることがわかった。

今後の課題としては, 会話の立場の違いを考慮して端末 間同期制御を拡張することが挙げられる．また，作業に応 じて端末間同期制御の有無を動的に切替えられるように制 御を拡張する予定である. そのため, 端末間同期制御が有 効な作業とそうでない作業の分類も行う必要がある.

\section{〔文献〕}

1）栗田 孝昭: “多地点間映像音声通信サービスにおける会話立場の違いが 総合品質へ及ぼす影響,”信学技報, CQ2005-32 (2005)

2) F. Gong: "Multipoint audio and video control for packet-based multimedia conferencing," Proc. ACM Multimedia, pp. 308314 (1996)

3) Y. Ishibashi, M. Nagasaka, and N. Fujiyoshi: "Subjective asscssment of fairness among uscrs in multipoint communications," Proc. ACM SIGCHI ACE (2006)

4) Y. Hashimoto and Y. Ishibashi: "Influences of network latency on interactivity in networked rock-paper-scissors," Proc. ACM NetGames (2006)

5) Y. Ishibashi and S. Tasaka: "A distributed control scheme for group synchronization in multicast communications," Proc. ISCOM, pp. 313-323 (1999)

6) Y. Ishibashi, S. Tasaka, and Y. Tachibana: "Media synchronization and causality control for distributed multimedia applications," IEICE Trans. on Communications, E84-B, 3, pp. 667677 (2001)

7) Y. Ishibashi, S. Tasaka, and Y. Tachibana: "Adaptive causality and media synchronization control for networked multimedia applications," Conf. Rec. IEEE ICC, pp. 952-958 (2001)

8) K. Hosoya, Y. Ishibashi, S. Sugawara, and K. E. Psannis: "QoE assessment of group synchronization control in distributed virtual environments," IEICE Technical Report, CQ2008-18 (2008)

9) ITU-T P.920: "Interactive test methods for audiovisual communications," (2000)

10) M. Carson and D. Santay: "NIST Net - A Linux-based network emulation tool," ACM SIGCOMM Computer Communication Review, 33, 3, pp. 111-126 (2003)

11) G. Blakowski and R. Steinmetz: "A media synchronization survey: Reference model, specification, and case studies," IEEE J. Sel. Areas in Commun., 14, 1, pp. 5-35 (1996)

12) Y. Ishibashi and S. Tasaka: "A synchronization mechanism for continuous media in multimedia communications," Proc. IEEE INFOCOM, pp. 1010-1019 (1995)

13) ITU-R BT.500-11: "Methodoly for the subjective assessment of the quality of television picture," (2002)

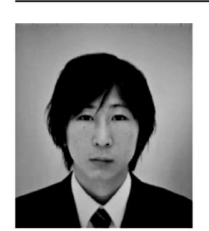

ほそ細谷 和輝 2008 年, 名古屋工業大学工学部情報工 学科卒業. 現在, 同大学院工学研究科創成シミュレーショ ン工学専攻博士前期課程に在学中. マルチメディア通信 における QOS 制御の研究に従事.

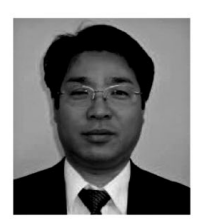

石橋 蝠 1981 年, 名古屋工業大学工学部情報 工学科卒業. 1983 年, 同大学大学院修士課程修了. 同年 日本電信電話公社入社. NTT ヒューマンインタフェー 研究所主任研究員を経て, 1993 年より名古屋工業大学 工学部電気情報工学科助教授. 現在, 同大学大学院教授. 分散マルチメディアの研究に従事. 工学博士. 正会貝.

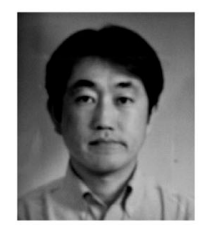

势わら 管原真司 1994 年, 東京工業大学工学部電気電子 工学科卒業. 1996 年, 同大学大学院修士課程修了. 1999 年, 同大学大学院博士課程修了. 同年電気通信大学電気 通信学部情報通信工学科助手. 2005 年, 名古屋工業大学 大学院助教授. 現在, 同大学大学院准教授. 分散データ ベース, 情報検索型通信の研究に従事. 博土 (工学). 